\title{
Prisión política y destierro en la Argentina dictatorial. Materiales y preguntas para la construcción de nuevos objetos de estudio
}

\author{
Political imprisonment and exile in the dictatorial Argentina. Materials and \\ questions for the construction of new objects of study
}

\author{
Silvina Jensen* y María Lorena Montero**
}

\begin{abstract}
Resumen: Este artículo se propone analizar las formas de abordaje de las relaciones entre cárcel y exilio haciendo foco en escenarios, luchas y actores concretos del pasado reciente argentino, a partir del análisis de materiales producidos por los desterrados en su accionar anti-dictatorial, en diálogo con otros emanados del propio sistema penitenciario o con las memorias de los protagonistas.
\end{abstract}

Palabras clave: dictadura, prisión, exilio, Comisión Argentina de Derechos Humanos, Historia Reciente

\begin{abstract}
This article aims to discuss ways of addressing the relationship between prison and exile by focusing on scenarios, struggles and specific actors of the Argentine recent past, from the analysis of materials produced by the exiles in their anti-dictatorial action, in dialogue with others issued the correctional system or the memories of the protagonists.
\end{abstract}

Key words: dictatorship, prison, exile, Argentina Human Rights Commission, Recent History.

\section{Introducción}

\footnotetext{
* Argentina, coautora. Doctora en Historia y Magister en Historia Moderna y Contemporánea por la Universidad Autónoma de Barcelona. Es investigadora Adjunta del CONICET, profesora Ordinaria de grado y posgrado en la carrera de Historia del Departamento de Humanidades de la Universidad Nacional del Sur (Bahía Blanca). sjensen@ criba.edu.ar

** Argentina, coautora. Licenciada y Profesora en Historia por la Universidad Nacional del Sur, institución en la que actualmente se desempeña como docente ordinaria de grado. Doctoranda en Historia y becaria del Consejo Nacional del Consejo de Investigaciones Científicas y Técnicas (CONICET). lorenamonter@gmail.com
} 
Este trabajo ${ }^{1}$ se propone analizar las relaciones entre prisión y exilio político en la Argentina dictatorial, atendiendo a dos campos de estudio que, hasta el momento y salvo excepciones, vienen transitando por cauces paralelos, y donde - excluyendo las investigaciones ligadas a los "opcionados" y algunas producciones testimoniales que en los últimos años avanzan en la reposición de una mirada más comprehensiva - no abundan las propuestas que repongan el par cárcel-destierro como fases de un mismo dispositivo represivo, ni exploren las articulaciones específicas y situadas tejidas por presos y exiliados en orden a la producción de conocimiento acerca de la naturaleza del régimen instaurado tras el golpe de Estado de marzo de 1976 o de cara a la denuncia internacional de las violaciones a los Derechos Humanos (DDHH) en la contemporaneidad dictatorial.

Este artículo trata de pensar formas de abordaje de las relaciones entre cárcel y exilio haciendo foco en escenarios, luchas y actores concretos del pasado reciente, a partir del análisis de materiales producidos por los desterrados en su accionar antidictatorial, en diálogo con otros emanados del propio sistema penitenciario o con las memorias de los protagonistas. En tal sentido, pretendemos situarnos en las fronteras de los estudios del exilio y la cárcel, con el propósito de avanzar desde una somera aproximación a trayectorias individuales y colectivas y desde la interrogación de ciertos escenarios de lucha antidictatorial, hacia la escritura de una Historia que supere tanto la compartimentación represiva y la segmentación de subjetividades militantes, como la fractura entre una Argentina "de adentro" y una Argentina "de afuera" en términos de historiales de violencia estatal, resistencia y oposición.

El trabajo se divide en tres partes. La primera revisa las principales líneas de trabajo de las agendas de las historiografías del exilio y la cárcel durante la última dictadura, tratando de visualizar potencialidades y áreas de vacancia en términos de la articulación del par encierro-destierro. La segunda centra su interés en una organización de exiliados, la Comisión Argentina de Derechos Humanos (CADHU), de cara a pensar desde las trayectorias de sus referentes, en la dinámica institucional y en algunas acciones concretas de denuncia a lo largo del "Proceso de Reorganización Nacional", cómo los desterrados construyeron sentidos en torno al lugar de la cárcel en el entramado represivo. Se trata de reponer desde una exploración no sistemática de "materiales del exilio" algunas relaciones significativas que habilitan analizar a presos y exiliados como parte de un común universo punitivo y de luchas. Por último, la tercera parte dedicada a reconstruir la trayectoria vital de Walter Calamita -bahiense, detenido a disposición del Poder Ejecutivo Nacional (PEN), militante del Partido Revolucionario de los Trabajadores (PRT), beneficiado por la "opción y exiliado en Italia- pretende interrogar los cruces entre encierro y destierro, atendiendo especialmente al análisis de las huellas del exilio en los registros penitenciarios. La elección de Calamita guarda relación no sólo con la riqueza de su biografía personal en términos de nuestro objeto de interés, sino en la posibilidad de analizar diacrónicamente su experiencia de cárcel y exilio.

\section{La cárcel y el exilio en la agenda de la Historia Reciente}

\footnotetext{
${ }^{1}$ Una versión de este trabajo fue discutida en las VII Jornadas de Trabajo de Historia Reciente, realizadas en la Facultad de Humanidades y Ciencias de la Educación de La Plata entre el 6 y el 8 de agosto de 2014.
} 
La identificación de cárcel y exilio como objetos con carta de ciudadanía propia tiene, salvo escasas excepciones, apenas algo más de una década en la agenda de los estudios sobre el pasado reciente en Argentina. De hecho, como señalan en sus respectivas investigaciones Guglielmucci ${ }^{2}$, Garaño ${ }^{3}$, D’Antonio ${ }^{4}$, Yankelevich y Jensen ${ }^{5}$, cárcel y exilio no sólo parecen haber tenido escasa visibilidad en las luchas públicas por las memorias de la represión, la militancia y la denuncia antidictatorial, sino que su tratamiento en sede académica también ha acusado cierto retraso o cierta subrepresentación ${ }^{6}$ en relación con la pregnancia de las investigaciones sobre la desaparición forzada de personas y los centros clandestinos de represión, dimensiones que según Gabriela Águila ${ }^{7}$, sintetizan y definen "la naturaleza del régimen militar" argentino.

En la historiografía ${ }^{8}$ sobre el exilio ${ }^{9}$, la recuperación de las claves que habilitan su lectura política y colectiva no ha sido una tarea sencilla. Si bien en los últimos años, las

\footnotetext{
${ }^{2}$ Ana Guglielmucci, "Entrelazando memorias: Cuándo, cómo, y qué recuerdan un grupo de ex prisioneras políticas de la "cárcel de Villa Devoto", Avá Revista de Antropología, no 7, Posadas, junio 2005.

${ }^{3}$ Santiago Garaño, Entre resistentes e "irrecuperables": Memorias de ex presas y presos políticos (19741983), Tesis de licenciatura, FFyL, UBA, 2008 [mimeo].

${ }^{4}$ Débora D'Antonio, "Represión y resistencia en las cárceles de la última dictadura militar argentina", La revista del CCC [en línea], $\mathrm{n}^{\circ}$ 2, enero-abril de 2008. Disponible en: http: //www.centrocultural.coop/revista/articulo/29/, consulta 22/4/2014.

5 Pablo Yankelevich y Silvina Jensen, "La actualidad del exilio", Pablo Yankelevich y Silvina Jensen (comps.), Exilios. Destinos y experiencias bajo la dictadura militar, Buenos Aires, Libros del Zorzal, 2007, 919.

${ }^{6}$ Hoy en el territorio de los exilios políticos esta "subrepresentación" merece ser discutida o matizada. Para comprender la evolución del campo historiográfico de los exilios, véase: Silvina Jensen, "La historiografía del último exilio argentino: un territorio en construcción", X Jornadas Interescuelas/Departamentos de Historia, UNR y UNL, Rosario, 20-23 de setiembre, 2005, Cd- Rom; y Silvina Jensen, "Exilio e Historia Reciente. Avances y perspectivas de un campo en construcción", Aletheia, revista de la Maestría en Historia y Memoria de la FAHCE, UNLP, $\mathrm{n}^{\circ}$ 2, vol. 1, mayo 2011. Disponible en: http://www.aletheia.fahce.unlp.edu.ar, consulta 31/3/2014.

${ }^{7}$ Gabriela Águila, "La represión en la historia reciente argentina: fases, dispositivos y dinámicas regionales", Gabriela Águila y Luciano Alonso (coords.), Procesos represivos y actitudes sociales. Entre la España franquista y las dictaduras del Cono Sur, Buenos Aires, Prometeo, 2013, 97.

${ }^{8}$ Cabe aclarar que no adscribimos a una definición tan amplia de historiografía que incluya toda operación social reflexiva o imaginativa acerca del pasado. Pero tampoco reducimos la historiografía a los historiadores de formación. Para el caso del pasado reciente, se impone incluso con más fuerza que para otras especialidades pensar en un espacio de encuentro entre cientistas sociales y humanos, que a veces redunda en el trabajo interdisciplinario. Por lo tanto, cuando hablemos de producción de sentidos en sede académica consideraremos la de aquellos investigadores que desde su saber disciplinar y experto, tienen como objeto aquellos procesos y experiencias que siguen afectando nuestras subjetividades y sensibilidades, con independencia de que por formación hayan transitado o no las instituciones de la Historia. (Marina Franco y Florencia Levín, "El pasado cercano en clave historiográfica", Historia Reciente. Perspectivas y desafíos de un campo en construcción, Buenos Aires, Paidós, 2007).

${ }^{9}$ Existe cierto acuerdo en situar el inicio del último movimiento colectivo de expulsión/huida de población en los últimos meses de 1973 y especialmente tras la declaración del Estado de sitio en noviembre de 1974. Estas salidas discontinuas y originadas en el accionar de bandas paraestatales como la Triple A, pasaron constituirse tras el golpe castrense del 24 de marzo en un drenaje sostenido de población que no finalizó hasta que los militares abandonaron el gobierno. Para un estudio pormenorizado de las fases de salida de exiliados políticos, véase Silvina Jensen "Huidos, opcionados, liberados. Los exilios argentinos de la década de 1970", Beatriz Figallo y María Rosa Cozzani (eds.), Los de adentro y los de afuera. Exclusiones e integraciones de proyectos de nación en la Argentina y Latinoamérica, Buenos Aires, IDEHESI/ Unidad Ejecutora en Red del CONICET, 2013, 143-144.
} 
conexiones entre exilio y dictadura o exilio y Estado de excepción se multiplican en las investigaciones académicas - rompiendo con visiones que desde el rescate de trayectorias biográficas individuales o de recorridos intelectuales y artísticos o desde la historia social migratoria no siempre revelaban la politicidad del movimiento -, no pocas investigaciones continúan obliterando la triple dimensión política del último destierro argentino, a saber: el exilio como modalidad represiva, esto es, el desterrado en su situación de perseguido político; el exilio en tanto consecuencia de una militancia política o político-militar previa y a veces de una presencia o visibilidad público-política, más allá de su encuadramiento personal en partido u organización sindical o revolucionaria alguna; y los huidos en tanto opositores antidictatoriales, luchadores humanitarios o militantes partidarios de nuevo cuño en los países de residencia o en redes humanitarias transnacionales.

En este contexto pueden señalarse etapas que marcan énfasis diferenciales en la producción historiográfica sobre el último exilio argentino. Las primeras investigaciones preocupadas por reconstruir capítulos nacionales del último destierro ${ }^{10}$ centraron su atención en las disputas y fracturas político-ideológicas ${ }^{11}$ y en la identificación de escenarios o "momentos de tensión" 12 y conflicto antidictatorial (especialmente Mundial de Fútbol 1978 y guerra de Malvinas). Si bien todos estos trabajos ponían el acento en las estrategias de denuncia de la dictadura y, en mayor o menor medida, avanzaban en la elucidación de las acciones que los exiliados emprendieron en pos de calificar y conceptualizar el régimen inaugurado en marzo del '76; el lugar de las cárceles legales en el entramado punitivo y la situación de los presos políticos no constituyeron una problemática central. La preocupación por los comportamientos opositores de los exiliados en términos esclarecimiento de la naturaleza punitiva del régimen y el interés por las interacciones entre los huidos e interlocutores locales (en los países de residencia), dificultaron la atención pormenorizada a las acciones desplegadas por los desterrados en relación con los diferentes colectivos de afectados por la represión estatal. En este sentido, la primera historiografía del exilio contribuyó a presentar lecturas sintéticas de los esfuerzos denuncialistas realizados para desentrañar la naturaleza de la represión ejercida por las Fuerzas Armadas (FFAA), enfatizando -quizás, sin proponérselo- la situación de los "desaparecidos" por sobre la de asilados, presos políticos, familiares de represaliados, etc. De este modo, queda pendiente una exploración pormenorizada de las estrategias ensayadas por los desterrados -en sus diferentes asociaciones humanitarias, políticopartidarias, etc., y en las variadas geografías de la diáspora - para situar/ dimensionar y lograr reconocimiento en la esfera internacional de la situación de estos presos políticos argentinos, situación que no fue ajena al dispositivo represivo "desaparecedor".

Sin desconocer que las dimensiones represivas o la militancia exiliada estaban presentes en los trabajos pioneros del subcampo de los destierros, en el último quinquenio se han ido fortaleciendo nuevas líneas de pesquisa. Entre ellas, las que reconstruyen trayectorias individuales y grupales de militancia y en las que el exilio aparece sea como

\footnotetext{
${ }^{10} \mathrm{Si}$ bien hoy las diferentes geografías nacionales del último exilio argentino van concitando la atención de los investigadores (Bélgica, Suecia, Venezuela, Italia, Israel, EEUU, Australia), los trabajos más consolidados son los relativos a los tres países clave de la última diáspora: México, Francia y España.

${ }^{11}$ Pablo Yankelevich, Ráfagas de un exilio. Argentinos en México, 1974-1983, México, FCE, 2010.

${ }^{12}$ Marina Franco, El exilio. Argentinos en Francia durante la dictadura, Buenos Aires, Siglo XXI Editores Argentina, 2008.
} 
posibilidad para recrear y resignificar la acción política en condiciones de terrorismo de Estado, sea como escenario estéril para la acción política, sea como una última opción dilemática, jamás reivindicada y sólo asumida como mecanismo de sobrevivencia. En tal sentido, resultan muy productivos los trabajos centrados en el análisis del lugar asignado al exilio por la Nueva Izquierdas; sobre la acción política exterior de la izquierda tradicional (por caso Partido Comunista Argentino (PCA) que no fue una fuerza antidictatorial ${ }^{13}$ ); y también aquellos que hacen foco en la salida del país como el camino más propicio para desplegar estrategias internacionalistas (Partido Socialista de los Trabajadores -PST ${ }^{14}$ ). Si bien es posible pensar que las historias de las militancias exiliadas pueden abrir la puerta a la interrogación sobre las articulaciones entre los dispositivos represivos de la cárcel y el destierro y sobre las experiencias de encierro y de fuga al exterior en términos de instancias de politización y repolitización, esto es todavía una asignatura pendiente.

En paralelo y nutridas por la apertura de archivos estatales (de servicios de inteligencia, policías políticas de países vecinos, de los servicios penitenciarios, de agencias consulares y ministerios de Interior o Exterior), comienzan a articularse pesquisas que ya no asumen como supuesto la relación entre represión y exilio, sino que logran poner en evidencia, desde la reconstrucción pormenorizada y a ras de suelo, que el exilio fue un dispositivo utilizado por los terrorismos de Estado del Cono Sur - y también por la dictadura argentina - para neutralizar toda forma de oposición, resistencia y disenso, incluida aquella que desplegaban los refugiados de países vecinos residentes en el país ${ }^{15}$. En tal sentido, el exilio se dibuja como una práctica represiva compleja, que no sólo incluyó formas violentas de salida, legales o clandestinas (expulsiones de extranjeros residentes, "opciones" para nacionales a disposición del Poder Ejecutivo Nacional) y controles fronterizos para evitar las huidas y para limitar los reingresos de militantes bajo la forma de contraofensivas; sino también prácticas de vigilancia, espionaje, infiltración, secuestro, repatriación forzada al interior de las comunidades exiliares instaladas en terceros países, tanto dentro de la región, como en Latinoamérica y Europa ${ }^{16}$. Esta línea de abordaje es, quizás, la que está alumbrando de manera más decidida la articulación entre cárcel y exilio, en tanto pone de relieve en qué medida el egreso del país de cientos de militantes políticos argentinos y en forma particular de los que estaban a disposición del

\footnotetext{
${ }^{13}$ Natalia Casola, "El Partido Comunista de Argentina y el exilio en Europa durante la última dictadura militar. Caracterizaciones políticas, alianzas y disputas", Actas de las Jornadas de trabajo: exilios políticos del cono sur en el siglo XX, La Plata, UNLP, 2012. Disponible en: http: //jornadasexilios.fahce.unlp.edu.ar/ponencias, consulta 1/3/2014.

${ }^{14}$ Florencia Osuna, "El exilio del Partido Socialista de los Trabajadores en Bogotá (1976-1982) entre los discursos militantes y las miradas policiales", Silvina Jensen y Soledad Lastra (eds.), Exilios: militancia y represión Nuevas fuentes y nuevos abordajes de los destierros de la Argentina de los años setenta, La Plata, EDULP, 2014.

${ }^{15}$ Cecilia Azconegui, "Chilenos en Argentina, entre la protección del Alto Comisionado de las Naciones Unidas para los Refugiados (ACNUR) y la política de expulsión de la dictadura militar”, Silvina Jensen y Soledad Lastra (eds.), Exilios: militancia y represión Nuevas fuentes y nuevos abordajes de los destierros de la Argentina de los años setenta, La Plata, EDULP, 2014.

${ }^{16}$ Melisa Slatman, "Terrorismo de Estado y exilio: hipótesis exploratorias para una comparación entre los casos chileno y argentino", I Jornadas de Trabajo sobre Exilios Políticos del Cono Sur en el siglo XX. Agendas, problemas y perspectivas conceptuales, Facultad de Humanidades y Ciencias de la Educación y la Maestría en Historia y Memoria de la UNLP, 26-28 de septiembre de 2012.
} 
PEN y salieron haciendo uso de la "opción"17, fue el colofón de instancias represivas previas que incluyeron intimidación, secuestro, desaparición, tortura, reaparición, blanqueo y traslados por diferentes cárceles "legales" del sistema penitenciario, sobre todo las que formaban parte del circuito de "máxima seguridad". 18

Por su parte, la historiografía sobre las instituciones punitivas y los presos políticos también ha venido consolidando un espacio considerable en la Argentina en la última década. En el conjunto de esta sugerente producción académica, las líneas de indagación han sido variadas. Desde los trabajos pioneros de Judit Filc ${ }^{19}$ sobre la construcción de un tipo peculiar de lazos (cuasi de sangre o familiares) entre los prisioneros políticos; Ana Guglielmucci ${ }^{20}$ sobre las vivencias de encierro de un grupo de militantes revolucionarias en la cárcel de Villa Devoto; Silvina Merenson ${ }^{21}$ sobre la compleja identidad de "sobreviviente" de las ex presas políticas; a los más cercanos de Santiago Garaño y Werner Pertot $^{22}$ sobre la experiencia del universo carcelario desde la masacre de Trelew al "Proceso de Reorganización Nacional"; Débora D'Antonio ${ }^{23}$ sobre las dimensiones de género de la prisión política y a otros de Santiago Garaño ${ }^{24}$ sobre los "pabellones de la muerte" de la Unidad Penitenciaria (UP) 9 de La Plata; el subcampo de la prisión política bajo el Estado de excepción se va no sólo ampliando sino complejizando.

Sin embargo no parecen haber sido temas fundamentales para los especialistas de la cárcel, las alternativas vitales tras la salida del penal, ni la exploración de las formas en que los detenidos políticos lograban sacar información precisa para denunciar las condiciones

\footnotetext{
${ }^{17} \mathrm{La}$ "opción” es un derecho contemplado por la Constitución Nacional (Artículo 23) que establece que cuando por determinado clima político o de conmoción interior, el presidente declara el estado de sitio, el Ejecutivo tiene la prerrogativa de trasladar a detenidos considerados peligrosos dentro del territorio del país y eventualmente concederles el beneficio de salir del mismo. Sobre los "opcionados" puede consultarse Virginia Pisarello, "De presos a exiliados: los “opcionados" de la última dictadura militar”, XIII Jornadas Interescuelas/Departamentos de Historia, Universidad Nacional de Catamarca, 10-13 de agosto de 2011. Publicado en CD Rom, Catamarca, Editorial Científica Universitaria, Secretaría de Ciencia y Tecnología, Universidad Nacional de Catamarca, 2013.

${ }^{18}$ Dentro de las cárceles de máxima seguridad se encontraban la Unidad Penitenciaria (UP) 2 de Sierra Chica, la UP 9 de La Plata, la UP 1 de Coronda, la UP 1 de Córdoba, la UP 2 de Villa Devoto, la UP 6 de Rawson y la UP 7 de Resistencia (las tres últimas dependientes del Servicio Penitenciario Federal) Garaño, Entre resistentes e "irrecuperables..., op.cit.

${ }^{19}$ Judith Filc, Entre el parentesco y la política. Familia y dictadura, 1976-1983, Buenos Aires, Biblos, 1997. Judith Filc, "La cárcel de la dictadura: el poder reparador de la memoria compartida", Marcela Nari y Andrea Fabre (comps.), Voces de mujeres encarceladas, Buenos Aires, Catálogos, 2000.

${ }^{20}$ Ana Guglielmucci, Memorias desveladas: Una aproximación a la militancia revolucionaria a través de los recuerdos de un grupo de militantes y ex prisioneras políticas durante la década del setenta en Argentina, FFyL, UBA, 2003 [mimeo].

${ }^{21}$ Silvina Merenson, Y hasta el silencio en tus labios..." Memorias de las ex presas políticas del Penal de Villa Devoto en el transcurso de la última dictadura militar en la Argentina, Tesis de Maestría, IDES/IDAES/UNSAM, Buenos Aires, 2004 [mimeo].

${ }^{22}$ Santiago Garaño y Werner Pertot, Detenidos-aparecidos. Presas y presos políticos desde Trelew a la dictadura, Buenos Airess, Biblos/Latitud Sur, 2007.

${ }^{23}$ D'Antonio, op. cit. y Débora D'Antonio "Políticas de desarticulación de la subjetividad sexual y de género practicadas en la cárcel de Villa Devoto durante la última dictadura militar argentina (1976-1983)”, Estudios, n 25 , Córdoba, enero-junio 2011.

${ }^{24}$ Garaño, Entre resistentes e "irrecuperables..., op.cit. y Santiago Garaño, "Los pabellones de la muerte de la Unidad 9 de La Plata. Los límites difusos entre la represión legal y la clandestina”, Entrepasados, n 34, Buenos Aires, 2008.
} 
de vida en prisión o alertar sobre la situación de peligro inminente en que vivían los llamados "irrecuperables" (ley de fugas, "suicidios", etc.) o sobre los modos en que esta información circulaba y llegaba al exilio, gracias a la acción de familiares, abogados, sacerdotes, representantes diplomáticos de terceros países y mediante la activación de redes transnacionales humanitarias.

Esta vacancia tiene su correlato en el escaso interés que los investigadores de los exilios han mostrado por el estudio de cómo fue posible articular campañas de denuncia por personas concretas detenidas en las cárceles del terrorismo de Estado - campañas para conseguir la libertad, para salvaguardar su integridad física - o por el análisis de cómo se fue construyendo un conocimiento público en la esfera internacional sobre el alcance represivo del "Proceso de Reorganización Nacional", no sólo ni especialmente en relación al delito de la desaparición forzada de personas, sino también respecto a las modificaciones de las condiciones de detención en vísperas del golpe y sobre la siniestra circulación de detenidos entre los centros clandestinos y las cárceles "legales" y viceversa.

Si como afirma Santiago Garaño ${ }^{25}$, la cárcel fue para los detenidos por razones políticas una "escuela de militancia" que fijó a sus cuadros las formas de mantener el funcionamiento político de la organización puertas adentro de la prisión en base a "disciplina, lucha reivindicativa y delegatura"; no es menos cierto que aún con las enormes limitaciones que impuso la centralización de presos "peligrosos" y el endurecimiento de las condiciones de detención a mediados de 1975, en consonancia con la transformación más estructural de la estrategia represiva ${ }^{26}$; los presos pensaron e intentaron que el extramuros carcelario y el exilio funcionaran como cajas de resonancia y como articuladores de acciones de resistencia que pudieran contribuir a su liberación o al reaseguro de los derechos fundamentales de cualquier detenido. La rapidez con la que tomaron forma en el exterior las denuncias sobre la dureza de las condiciones de encierro en las diferentes cárceles de "máxima seguridad" y las noticias que la prensa extranjera publicaba casi en tiempo real sobre falsos intentos de fuga o sobre demandas ante terceros gobiernos, partidos políticos o asociaciones humanitarias de países de residencia de exiliados, permiten poner entre paréntesis la completa fractura entre un interior y un exterior carcelarios, o al menos ayudan a matizar/ complejizar e historizar ${ }^{27}$ las articulaciones entre encierro y destierro.

En este contexto, consideramos que mientras la historiografía sobre la prisión política ha avanzado de forma sostenida en mostrar el continuun entre cárceles y centros

\footnotetext{
${ }^{25}$ Garaño, Entre resistentes e "irrecuperables..., op.cit., 30 y 43.

${ }^{26}$ Explica D’Antonio (Represión y resistencia en las cárceles..., op.cit.) que desde mediados de 1975 y conforme los militares se hicieron con el poder, los detenidos en las cárceles provinciales o de Capital Federal "sufrieron un tratamiento similar al de las personas "desaparecidas". Su periplo carcelario, que comenzaba con una detención ilegal y que sucedía a altas horas de la noche entre golpizas y capuchas, finalizaba con el paso por casas para interrogatorios, centros de detención clandestinos o algún sótano de aplicación de tormentos ilegal de jefatura policiales. Aunque quienes caían presos en cárceles legales tenían mayores posibilidades de sobrevivir, incluso en este punto, estos espacios de encierro reproducían la ilegalidad de los "chupaderos" recurriendo a excusas como la tan mentada "ley de fugas".

${ }^{27}$ Siempre teniendo en cuenta la heterogeneidad de redes capaces de ser activadas y el capital relacional diferencial que cada preso o mejor cada formación política o política-militar disponía y, en no menor medida, atendiendo a la temporalidad represiva del régimen (relativamente más "sencillo" pese a las requisas, la censura y la tortura, en 1978/79 que tras el golpe de Estado).
} 
clandestinos de detención durante la última dictadura ${ }^{28}$, su agenda aún tiene abierta la posibilidad de interrogarse sobre las articulaciones entre espacios de detención (legales y clandestinos) y diferentes formas de exilio, a saber, la situación de aquellos que habían vivido como refugiados o asilados en el país desde 1973 (chilenos ${ }^{29}$, uruguayos, paraguayos, bolivianos y brasileños), los extranjeros e incluso argentinos naturalizados que fueron expulsados tras ser detenidos y acusados en los términos de la Ley de Seguridad $(20.840)^{30}$, y los que salieron del país bajo el derecho de "opción"31, que como afirmaban Raimundo Ongaro e Hipólito Solari Yrigoyen, convertía al que se iba en una especie de "deportado" o "desterrado". ${ }^{32}$ Y esto apelando tanto a la recuperación de memorias personales o a la consulta de testimonios en primera persona de la etapa dictatorial, como a su entrecruzamiento con registros de la burocracia penitenciaria, normas del Estado nacional (en particular ley 20.840/74, Acta para el Proceso de Reorganización Nacional, ley

${ }^{28}$ Para un análisis de los puentes que hicieron de los dos universos de detención ámbitos emparentados durante la última dictadura, véase: Pilar Calveiro, "Introducción", Santiago Garaño, y Werner Pertot, Detenidos-Aparecidos. Presas y presos políticos desde Trelew a la dictadura, Buenos Aires, Biblos, 2007, 17.

${ }^{29}$ Para un análisis pormenorizado de la situación de los refugiados en un "problema de seguridad" tanto a nivel de la normativa, como de las acciones de las fuerzas represivas (legales o ilegales) que se concretó en allanamiento de organizaciones de asistencia a perseguidos residentes en el país e incluso a dependencias del Alto Comisionado de Naciones Unidas para los Refugiados (ACNUR), véase Azconegui (op.cit.) y Enrique Serra Padrós y Melisa Slatman, "Brasil y Argentina: modelos represivos y redes de coordinación durante el último ciclo de dictaduras del Cono Sur. Estudio en clave comparativa y transnacional", Silvina Jensen y Soledad Lastra (eds.), Exilios: militancia y represión Nuevas fuentes y nuevos abordajes de los destierros de la Argentina de los años setenta, La Plata, EDULP, 2014.

${ }^{30}$ La Ley 20.840, de Seguridad Nacional o del Estado, sancionada el 28 de septiembre de 1974 durante el gobierno de María Estela Martínez de Perón y mantenida por la Junta Militar, contemplaba penas por actividades subversivas. En el texto preveía penas de prisión de entre "tres a ocho años, siempre que el hecho no constituyere un delito más severamente penado, el que para lograr la finalidad de sus propósitos ideológicos, intente o preconice por cualquier medio, alterar o suprimir el orden institucional y la paz social de la Nación, por vías no establecidas por la Constitución Nacional y las disposiciones legales que organizan la vida política, económica y social de la Nación" (Art. 1). Asimismo, sancionaba los "actos de divulgación, propaganda o difusión tendientes al adoctrinamiento, proselitismo o instrucción de las conductas previstas en el Art. 1" (Art. 2) e incluía penas accesorias para argentinos naturalizados y extranjeros, que involucraban "pérdida de ciudadanía y expulsión del país al término de la condena" (Art. 9) (Boletín Oficial de la República Argentina -BORA-, 2/10/1974, 2).

${ }^{31}$ Refiriéndose a la "opción”, Carlos Brocato afirmaba: “qqué otra cosa que destierro ordenado ha sido el artilugio leguleyo con que la dictadura transformó la 'opción para salir del país' bajo Estado de sitio? Curiosa opción la que quedó después: el que optaba era el Poder Ejecutivo. Primero confinaba al reo de un modo singular en una institución carcelaria, en un campo de concentración clandestino o en un mero y tenebroso 'chupadero'. Como se ve, este peculiarísimo Poder Ejecutivo-Dictadura se autoconfería opciones varias. Podía mantenerlas o cambiarlas, u otorgar la gracia de que el sospechoso se marchara a perpetuidad del país, porque perpetuo era el estado de sitio" (Carlos Brocato, El exilio es nuestro, Buenos Aires, SudamericanaPlaneta, 1986, 74).

${ }^{32}$ No hay que olvidar que la Junta Militar operó en relación a la aplicación de la "opción" de dos formas. Por un lado - como señaló Amnistía Internacional en su Informe de 1977 - suspendiéndolo incluso de forma retrospectiva (Decreto 21.338, 29/3/1976) - hecho que afectó a los detenidos que tenían concedida la "opción" antes del golpe y aún no habían concretado su traslado fuera del país -; y por el otro, aplicándolo con absoluta arbitrariedad y discreción y atendiendo a razones de "seguridad nacional" (Movimiento Peronista Montonero (MPM), Informe sobre la represión en Argentina, 1978, s.p.i..). Según Solari Yrigoyen, sobre los "opcionados" pesaba la imposibilidad de regresar al país. Su regreso constituía un "delito de regreso ilegítimo" (Daniel Parcero, et. al., La Argentina Exiliada, Buenos Aires, CEAL, 1985, 137). 
$21.259 / 76^{33}$, etc.), disposiciones de la Dirección General de Migraciones dependiente del Ministerio del Interior y decretos presidenciales de expulsión y "opción”.

\section{La CADHU y la solidaridad multilateral con los presos políticos. Aproximación a las articulaciones entre cárcel y exilio desde fuentes del destierro}

Una vía para ingresar a las complejas articulaciones entre cárcel y exilio durante la última dictadura la proporciona la trayectoria de la Comisión Argentina de Derechos Humanos (CADHU).

Autodefinida como una "organización civil y no partidaria" y conformada "por personalidades políticas, científicas, culturales, religiosas y hombres de derecho"; desde sus orígenes, la Comisión se fijó un objetivo fundamental: coordinar la "denuncia y solidaridad" no a escala territorial, sino transnacional ${ }^{34}$, apelando al respeto del Derecho Internacional Humanitario y la Constitución Nacional. ${ }^{35}$

A poco de su fundación en Argentina en abril de $1976^{36}$ tras la persecución, asesinato y desaparición de sus principales referentes, quedó reducida a su "Delegación Internacional", en sus sedes formales de Madrid, París y Washington, y con presencia no

\footnotetext{
${ }^{33}$ Ley que regulaba los "casos en que se procederá la expulsión de un extranjero", sea residente permanente o no permanente. La ley se aplicaba en caso de que tuviera una condena en el extranjero y lo hubiera ocultado, "cuando fuere condenado por la justicia argentina por delito doloso; cuando realizare en la República actividades que afecten la paz social, la seguridad nacional o el orden público" (BORA, 24/3/76). Resulta interesante observar que esta ley fue aplicada a personas nacidas en el exterior pero que al momento de la expulsión eran ciudadanos argentinos. Un caso interesante es el del militante del FAL 22, José María Company Céspedes, nacido en Asturias, acusado por la ley 20.840, preso en la UP9 y la UP2, reclamado internacionalmente (Cambio 16, Madrid, 23/8/76) y expulsado por decreto de febrero de 1978.

${ }^{34}$ En buena medida el temprano reconocimiento de la coordinación represiva a escala regional y el foco puesto en la situación de peligro en que vivían los asilados y refugiados del Cono Sur residentes en la Argentina, abrieron las puertas a una apuesta por el trabajo no acotado a los países donde la CADHU tenía sedes. En tal sentido, sus principales interlocutores fueron NNUU, Parlamento Europeo, Comisión Interamericana de Derechos Humanos (CIDH) de la OEA, Comisión Internacional de Juristas (a la que perteneció Mattarollo), Cruz Roja Internacional, Amnistía Internacional, Pax Romana o Justicia y Paz, evaluados como foros de internacionalización de la situación argentina e instrumentos para la construcción de una "solidaridad multilateral" (CADHU París. Boletín no 4, junio-julio de 1978).

${ }^{35}$ CADHU. Conferencia de prensa, Ginebra, 21/2/1977.

${ }^{36}$ En la entrada correspondiente a la documentación de la CADHU México, el Archivo Nacional de la Memoria afirma que la CADHU comenzó a funcionar en febrero de 1976. Allí se señala que el grupo original estuvo integrado por Eduardo Luis Duhalde, Haroldo Logiurato, Liliana Galletti, Ignacio Ikonicoff, Marcelo Duhalde y Carlos María Duhalde. Luego se incorporaron Mario Hernández, Roberto Sinigaglia, Gustavo Roca, Carlos González Gartland, Mario Abel Amaya, Lucio Garzón Maceda, Manuel Gaggero, Vicente Zito Lema, Daniel Antokoletz, Gustavo Varela, Juan Carlos Caprioli, Marta Taboada y Elvira Ellacuría de del Castillo. Para mayor información, véase http://anm.derhuman.jus.gov.ar/fanm_colec_institucional.html, consulta 23/4/2014. Por su parte Marina Franco y Pilar García Bernaldo afirman que la CADHU había surgido en 1975 de un acuerdo entre el PRT y Montoneros, que desde 1976 tuvo su núcleo fundamental en Madrid y en 1977 creó su sección francesa (Marina Franco y Pilar García Bernaldo, "Cuando el sujeto deviene objeto: la construcción del exilio argentino en Francia", Pablo Yankelevich (comp.), Represión y destierro. Itinerarios del exilio argentino, La Plata, Al Margen, 2004, 29)
} 
orgánica en México, Holanda, Bélgica, Suiza y Suecia ${ }^{37}$. Si bien por la CADHU pasaron numerosas personalidades - sobre todo abogados penalistas y laboralistas ${ }^{38}$, intelectuales, periodistas y $\operatorname{artistas}^{39}$, en su mayoría claramente filiadas con las organizaciones revolucionarias (Montoneros sobre todo, pero también militantes de la izquierda marxista y trotskista) ${ }^{40}$-; hacia 1978 esa "Delegación Internacional" contaba con el trabajo cotidiano y continuado de Gustavo Roca ${ }^{41}$, Eduardo Duhalde ${ }^{42}$ (Madrid), Lidia Massaffero ${ }^{43}$ (Roma,

37 Para conocer parte de la compleja historia de la CADHU, véase: Guillermo Mira Delli-Zotti, "La singularidad del exilio argentino en Madrid: entre las respuestas a la represión de los '70 s y la interpelación a la Argentina posdictatorial", Pablo Yankelevich (comp.), Represión y destierro. Itinerarios del exilio argentino, La Plata, Al Margen, 2004; Franco, El exilio. Argentinos en..., op.cit.; Yankelevich, Ráfagas de un exilio..., op.cit.; y Luciano Alonso, Defensa de los Derechos Humanos y cultura política entre Argentina y Madrid, 1975-2005, Tesis de Maestría, Universidad Nacional de Andalucía, 2010.

${ }^{38}$ Sobre los integrantes de la primitiva CADHU represaliados (Mario Hernández, Mario Amaya, Daniel Antokoletz, Roberto Sinigaglia, Marta Taboada, entre otros), muchos de los cuales habían integrado desde principios de los '70 la Asociación Gremial de Abogados y otros agrupamientos de letrados comprometidos con la defensa de presos políticos y gremiales y/o claramente identificados con las organizaciones revolucionarias, véase Abogados desaparecidos defensores del pueblo. Semblanzas de los abogados y abogadas detenidos/as-desaparecidos/as y asesinados/as entre 1970 y1983 en la Argentina, Buenos Aires, Defensoría General de la Ciudad de Bs As-Asociación de Abogados de Buenos Aires, 2014. También Mauricio Chama "Movilización y politización: abogados de Buenos Aires entre 1968 y 1973", Anne PerotinDumon, (dir), Historizar el pasado vivo en América Latina, 2007. Disponible en: http://etica.uahurtado.cl/historizarel pasadovivo7es_contenido.php, consulta 20/4/2014.

39 Por ejemplo Alipio Paoletti, Julio Cortazar, Julio Le Parc, Vicente Zito Lema, David Viñas, Ricardo Carpani o Humberto Constantini.

${ }^{40}$ Cabe señalar que en un voluminoso dossier de la inteligencia militar titulado Acciones contra Argentina sobre Derechos Humanos. Marco exterior (s.f.) (Archivo DIPBA) se afirmaba: "La CADHU es el resultado del acuerdo establecido entre Montoneros, PRT-ERP, Partido Comunista Marxista leninista, Partido revolucionario de los Obreros Argentinos, asimismo han participado del acuerdo subversivo otras bandas tales como el Grupo Obrero Revolucionario, Frente Revolucionario 17 de Octubre y Juventud Irigoyenista. Sus integrantes son los Delincuentes Terroristas (DDTT). Entre los integrantes del Comité Ejecutivo figuran los abogados..."

${ }^{41}$ Como representante de la CADHU le cupo la responsabilidad de presentar el 28 y 29 de septiembre de 1976, la primera gran denuncia internacional contra la dictadura en el congreso de los EE.UU. Lo acompañó otro integrante de la Comisión, Lucio Garzón Maceda, abogado laboralista que se radicó en París por la cercanía con el epicentro de la denuncia (Ginebra, sede de las NNUU). Ambos habían huido del país por Paso de los Libres, pasando por Brasil hacia Europa.

42 Abogado de la Unión Obrera Metalúrgica junto a Ortega Peña, fue autor de la investigación sobre el "primer desaparecido" de la Argentina, el delegado metalúrgico Felipe Vallese. Ambos integraron la Gremial de Abogados de Buenos Aires. Ligados al Peronismo de Base, Ortega Peña se desempeñó como diputado hasta su asesinato en manos de la Alianza Anticomunista Argentina (AAA) y Duhalde dirigió la revista Militancia Peronista para la Liberación desde donde combatió a la derecha peronista. Tras la muerte de su amigo y antes de su exilio madrileño -derivado de su inclusión en el Acta Institucional de la Junta que lo privó de sus derechos ciudadanos -, Duhalde inició un proceso de revisión de la lucha armada en el Partido Revolucionario de los Obreros Argentinos (PROA). Fue si no autor en solitario, como mínimo el alma mater del primer documento de denuncia integral del régimen militar, Argentina. Proceso al Genocidio, editado en Madrid en marzo de 1977 y luego traducido al francés en la coyuntura del Mundial de Fútbol '78. Este libro, según explica Gustavo Roca, fue elaborado en Buenos Aires y recogía lo expuesto meses antes ante el congreso norteamericano (Hugo Quiroga y César Tcach (comps.), Argentina, 1976-2006. Entre la sombra de la dictadura y el futuro de la democracia, Rosario, Homo Sapiens, 2006, 244). Según Marcelo Duhalde, su hermano se llevó al exilio apuntes personales e informes elaborados por compañeros abogados y militantes que se habían movilizado en la coyuntura del golpe. La edición y distribución del libro fue posible gracias al aporte económico del cineasta Elías Querejeta (Tiempo Argentino, 17/8/2012). Su repercusión en España fue 
Madrid $\mathrm{y}$ otras ciudades europeas), Rodolfo Mattarollo ${ }^{44}$ (París), Manuel Gaggero $^{45}$ (Madrid, Nicaragua) y Carlos González Gartland ${ }^{46}$ (México). ${ }^{47}$

A continuación y a partir de una serie de ejemplos ${ }^{48}$ queremos mostrar cómo las campañas de denuncia que protagonizó la CADHU en el exterior y su propia dinámica institucional $^{49}$, permiten transitar los puentes que conectan cárcel y exilio, mostrando las

inmediata. El 10 de abril de 1977, El País publicaba en la sección Cultura un artículo titulado "El genocidio argentino", que atribuía al libro haber asestado uno de los "golpes más contundentes" a la Junta que debería explicar la "magnitud de la tragedia que vive el pueblo argentino". A lo largo del exilio fue habitual que otras organizaciones (Comisión de Solidaridad de Familiares de Muertos, desaparecidos y Presos Políticos (COSOFAM), Comité de Solidaridad con el Pueblo Argentino (COSPA), Comité Argentino de Información y Solidaridad (CAIS), etc.) usaran el libro para fundamentar sus denuncias.

${ }^{43}$ Su inicio en la militancia se remonta a 1971, tras el asesinato de su hijo Manuel Belloni, enrolado en las filas de las Fuerzas Armadas Peronistas. Habiendo pasado por la cárcel y siendo beneficiada por la amnistía camporista, conoció en calidad de defensores a Ortega Peña y Duhalde. Tras salir al exilio junto a Juan Gelman, protagonizó el lanzamiento del Movimiento Peronista Montonero en Roma en 1977. En febrero de 1979, ya desde su exilio madrileño rompió con la organización por su desacuerdo con la Contraofensiva (Adriana Bernardotti y Bárbara Bongiovanni, “Aproximación al estudio del exilio argentino en Italia”, Pablo Yankelevich (comp.), Represión y destierro. Itinerarios del exilio argentino, La Plata, Al Margen, 2004, 61). En Roma, había trabajado muy tempranamente (1975) junto a Delia Fanego (Delia Ana Fanego (comp.), Quebrantos. Historias del exilio Argentino en Italia, Buenos Aires, Ediciones Fabro, 2010) en el comité que más tarde sería conocido como Comité Antifacista contra la Represión en Argentina (CAFRA) y en Madrid, tuvo un desempeño central en la CADHU.

${ }^{44}$ Fue miembro de la Asociación Gremial de Abogados de Buenos Aires junto a Ortega Peña, Eduardo Duhalde, Mario Amaya y Roberto Sinigaglia quienes desde las dictaduras de Onganía, Levingston y Lanusse defendieron presos políticos y destacaron representando a los sobrevivientes de la masacre de Trelew. Militante del Partido Revolucionario de los Trabajadores-Ejército Revolucionario del Pueblo (PRT-ERP), integró la Junta Coordinadora Revolucionaria y dirigió Nuevo Hombre durante 1974. Se exilió en París donde integró la CADHU hasta 1979.

45 Militante del peronismo cookista, abogado de la Confederación General del Trabajo (CGT) de los Argentinos en 1968, preso político en 1970 y cofundador del Frente Antiimperialista y por el Socialismo (FAS). Dirigió el diario El Mundo entre diciembre de 1973 y marzo de 1974. En 1974 pasó a la clandestinidad integrando las filas del PRT-ERP, que decidió resguardarlo enviándolo a España, donde continuó su trayectoria de defensor de presos políticos y sociales, incorporándose a la CADHU. Tras la fractura del partido, Gaggero se encolumnó en la línea de Enrique Gorriarán Merlo y se sumó a la Revolución Sandinista.

${ }^{46}$ Referente de la CADHU en México DF, es junto a Duhalde (fallecido en 2012) y Pedro Galín, uno de los pocos sobrevivientes de la Gremial que habían actuado en 1972 atendiendo a la situación de los fugados del penal de Rawson y de los sobrevivientes de la "masacre de Trelew".

${ }^{47}$ CADHU Madrid, Fundamentos y bases para una reorganización y reestructuración, 19/3/1978.

${ }^{48}$ Estos ejemplos sólo pretenden alertar sobre lo productivo de una investigación sistemática sobre las articulaciones entre encierro y destierro a partir de la exploración de documentación generada por o en las diferentes geografías del exilio. Del mismo modo, la última parte del trabajo, elige la trayectoria de un preso que luego marchó al exilio, para verificar las potencialidades de las fuentes burocráticas en la elucidación de estos cruces.

${ }^{49} \mathrm{La}$ CADHU no sólo tuvo de un origen en territorio argentino en torno al golpe y ligado a la defensa de presos políticos, sino que a lo largo de su historia transnacional supo capitalizar la experiencia de organización y lucha durante la "Revolución Argentina" para un nuevo contexto represivo y de cara a documentar el terror de Estado y tipificar la desaparición forzada de personas como delito de lesa humanidad. Dos notas que ilustran lo dicho: Daniel Antokoletz - hermano de María Adela de Madres de Plaza de Mayo había defendido presos políticos en Argentina y en Chile. Como especialista en Derecho Internacional Público, denunció las violaciones al derecho de asilo. Secuestrado en noviembre de 1976, sus borradores mecanografiados del estatuto de la CADHU fueron sacados clandestinamente y aprobados en España en diciembre de 1976. Por su parte Mario Hernández, que había integrado la Agrupación de Abogados 
potencialidades de un nicho historiográfico en la frontera de dos subcampos que hasta el presente vienen marchando por carriles paralelos.

A dos años del golpe de Estado, Eduardo Duhalde exponía en la revista española Triunfo las "cifras" de la represión: "8.000 personas directamente asesinadas, otras 20.000 secuestradas por las fuerzas de seguridad -la mayor parte muerta en los campos de concentración tras inenarrables torturas- y 10.000 presos políticos en las cárceles "oficiales"...". En la revista madrileña, el titular de la CADHU reclamaba reforzar el cerco internacional, sin paralizarse ante el horror de las "cifras". A su juicio, quedarse en la enumeración de las víctimas podía obturar la explicación de "las causas de este terrorismo de Estado", o la elucidación de las razones profundas del comportamiento de los militares, que lejos estaban de ser "irracionales o arbitrarios en su crueldad, al modo de esos tiranuelos de republiquetas". Para Duhalde, la situación de los detenidos ${ }^{50}$ y de los secuestrados era una consecuencia querida de "la aplicación fría y planificada del proyecto de exterminio de la militancia política y de los sectores más activos y de vanguardia de la clase obrera, tendiente al dominio y sometimiento del conjunto de los trabajadores". 51

¿Cuál fue el trabajo de la CADHU en relación con la prisión política? ¿En qué medida lo que ocurría en las cárceles "oficiales" de la dictadura fue para esta organización del exilio parte constitutiva de ese proyecto represivo ejecutado "por el conjunto de las FFAA", con el "apoyo" del "Pentágono" y el "respaldo" de las "multinacionales" ("ITT, ESSO, Siemens, Banca Morgan") para la "superexplotación obrera y la concentración de la actividad económica?". 52

En primer lugar, la CADHU mostró muy tempranamente que existían presos políticos antes del 24 de marzo, cuyas condiciones de detención comenzaron a endurecerse desde mediados de 1975. Sin embargo, al menos hasta el golpe fue posible "individualizarlos", porque en una vasta proporción estaban sometidos a procesos judiciales o arrestados a disposición del PEN. Mientras parlamentos, tribunales, partidos políticos, organizaciones sindicales y organizaciones de solidaridad funcionaban en el país, fue posible obtener un "mínimo de información" de fuentes oficiales. Tras la toma del poder por las FFAA, el silencio y el secreto se impusieron. La Junta operó en relación con los presos políticos siguiendo la misma lógica que respecto a los secuestrados ("desaparecidos"): ocultando su número exacto "para cuidar su ya deteriorada imagen internacional y para intentar diferenciarse de las dictaduras militares chilena y uruguaya, ya definitivamente condenadas por los actos de verdadero genocidio cometidos contra sus pueblos". 53

Peronistas, también se sumó al proyecto de creación de la CADHU. Antes de su secuestro en mayo de 1976, Hernández había podido reactivar una red de contactos internacionales de la época de Lanusse cuando como parte de los abogados del peronismo combativo denunció la situación de los presos políticos en foros de Europa.

50 Entre sus principales programas de ayuda, la CADHU tuvo uno orientado a "prisioneros políticos, familiares de prisioneros políticos y /o de personas desaparecidas o asesinadas; otro de reagrupamiento familiar: salida de niños; otro de auxilio a la "salida y ayuda a refugiados políticos argentinos en tránsito en países latinoamericanos" y un tercero de "salida de emergencia de argentinos detenidos a disposición del PEN” (CADHU París. Boletín n ${ }^{\circ} 4$, junio/julio 1978).

${ }^{51}$ Triunfo, $1 / 4 / 1978$.

${ }^{52}$ Idem.

${ }^{53}$ CADHU, Argentina. Proceso al genocidio, Madrid, Elías Querejeta, 1977, 58-60. 
En segundo lugar, la CADHU denunció la aplicación sistemática de la tortura en las cárceles legales, práctica antigua en la Argentina, pero que en sus actuales formas empezó a institucionalizarse durante los gobiernos de la "Revolución Argentina", para asumir después del golpe una modalidad sólo equiparable a la de la Alemania nazi, el Vietnam ocupado por los yankis o la Argelia bajo dominio francés. ${ }^{54}$

En tercer lugar, la CADHU señaló que el sistema carcelario durante el "Proceso de Reorganización Nacional" era "cruel e inhumano". Videla "legalizó" mediante resoluciones y decretos condiciones cada vez más "restrictivas y rigurosas para los ciudadanos encarcelados". Pero si "las cárceles se ha[bían] transformado de hecho en feroces campos de concentración y en recintos donde la inhumanidad y la bestialidad impera[ba]n impunemente"; desde su perspectiva, la impunidad total sólo fue posible en los "establecimientos no oficializados", donde no existía la mínima posibilidad de control y "se proseg[uían] las torturas y se aplica[ba]n sistemáticamente el suplicio del agua, la extracción o quema de uñas, los simulacros de fusilamientos, la exigencias de marchas y ejercicios agotadores". 55

En cuarto lugar y en la línea de explicar la compleja trama represiva, la CADHU alertaba que "el asesinato de prisioneros se ha[bía] transformado en norma y en sistema". Si en las "cárceles ilegales o no reconocidas", los detenidos eran "lisa y llanamente asesinados y sus cadáveres arrojados, en las "cárceles legales" se aplicaba la "ley de fugas". 56

En quinto lugar, la CADHU denunciaba que abogados y familiares de presos políticos fueron blancos preponderantes del Estado terrorista. Con respecto a los primeros, explicaba que la razón última de estas acciones fue dejar "en absoluta indefensión técnica y jurídica a los miles de prisioneros políticos argentinos, tanto los encarcelados durante el gobierno anterior, como los detenidos masivamente con posterioridad al golpe militar". Según la Comisión, se contaban por decenas los "abogados asesinados, secuestrados y presos" desde 1974, cifras a las que había que sumar "otros igualmente perseguidos que lograron eludir la muerte o la cárcel y que debieron abandonar el país y exiliarse"57. A su criterio, la persecución de los familiares apuntaba no sólo a sembrar el terror, sino a dejar a los detenidos sin vías de conexión con el exterior. La CADHU señalaba que si tras el golpe, las cárceles fueron incomunicadas, suprimiéndose visitas, entregas de medicamentos, ropa, libros, diarios, revistas y correspondencia; los familiares que se atrevieron a protestar o denunciar fueron sistemáticamente represaliados. Los casos de la Comisión de Familiares de Presos Políticos de Córdoba ${ }^{58}$ - encarcelados en grupo y más tarde intimidados mediante ${ }^{54}$ Ibid, 61.
55 Ibid, 65 y 66.
${ }^{56}$ La CADHU Madrid lanzó una acción urgente en la que denunciaba ante la comunidad internacional el
peligro inminente de fusilamiento que pesaba sobre Rodolfo Rodríguez, Oscar Montenegro y Horacio Crean,
recluidos en los Pabellones 1 y 2 de la UP 9, separados del resto de sus compañeros y amenazados de muerte
por personal militar. La CADHU alertaba sobre situaciones similares: el asesinato de Dardo Cabo, detenido
en Sierra Chica y muerto en un supuesto intento de fuga en su traslado a Olmos. Si algo sumaba fundamentos
a la sospecha de la CADHU era que Rodríguez, Montenegro y Crean compartían pabellón con otros 40 presos
entre los que figuraba el abogado, periodista y ex Secretario General del Sindicato de Prensa de Buenos Aires,
Eduardo Jozami, que debería haber quedado en libertad en diciembre de 1976 tal como lo establecía el
decreto PEN, pero a la fecha no se había concretado (CADHU Madrid, Boletín $\left.n^{\circ} 9,31 / 1 / 1977\right)$.
57 CADHU, Argentina. Proceso..., op.cit., $48-49$.
58 Resulta incesante observar la trascendencia del trabajo de esta Comisión de Familiares cordobeses. Sus
denuncias sobre la "aplicación de la ley de fugas" como forma progresiva de eliminar presos políticos, 
cartas supuestamente escritas por sus seres queridos, en las que les advertían sobre lo "inoportuno de sus visitas" -, de la madre de Dante Gullo ${ }^{59}$ - dirigente de la Juventud Peronista (JP) y preso en Sierra Chica -, o de la esposa del militante del PRT-ERP Eduardo Anguita $^{60}$ eran apenas emergentes de una política sistemática tendiente a silenciar la situación de los detenidos políticos y a bloquear la denuncia en el exterior. Pero además Duhalde indicaba que la persecución a abogados y familiares debía entenderse en el marco de un dispositivo represivo que lejos estuvo de ser indiscriminado. A su juicio, la selectividad represiva tuvo que ver tanto con el potencial "subversivo" de las víctimas, como con "el poder simbólico que el crimen adquí[ría]”. En tal sentido, la persecución, detención, asesinato o desaparición de familiares y abogados defensores pretendía instalar una identificación entre "militante político" y "peligro de vida". La acción punitiva buscaba que el familiar los repudiara, aislara y no reclamara; y que el defensor, depusiera su responsabilidad profesional, negándose a defender "subversivos". 61

Este cuadro temprano de la magnitud del problema de los presos políticos, de las relaciones entre las condiciones de las cárceles "legales" con la de otros espacios (semilegales y clandestinos) del circuito represivo y de los intentos castrenses por bloquear la información y la denuncia de las condiciones carcelarias, permitió a la CADHU avanzar en la explicación de la "racionalidad del terror". Para la Comisión, los penales fueron un engranaje fundamental de la "operación de cirugía" puesta en marcha por los militares para "asegurar la estabilidad del sistema capitalista" $"$. Pero, al mismo tiempo, su situación remitía a la vulneración de un conjunto de derechos individuales contemplados por la Constitución Nacional y la Declaración Universal de Derechos Humanos de las Naciones Unidas (NNUU), a saber: "derecho de libertad y seguridad individual", "arbitrariedad de las

llegaron tempranamente a la prensa española que explicaba que se trataba de "simples fusilamientos tras los cuales los comunicados oficiales informan sobre un frustrado intento de evasión" (El País, 18/11/1976).

${ }^{59}$ Angélica María Aieta, era ciudadana italiana y fue secuestrada de su domicilio en agosto de 1976. En un informe, la CADHU explicaba que había adquirido "notoriedad- denunciando la "situación de los presos políticos, entre ellos sus hijos" (CADHU, Argentina. Proceso..., op. cit., 55). Se estima que fue trasladada a la Escuela de Mecánica de la Armada (ESMA) y que fue víctima de los "vuelos de la muerte". Continúa desaparecida.

${ }^{60}$ En su testimonio desde la cárcel de Devoto difundido por la CADHU, Wanda Fragale de Anguita explicaba que era hija de ciudadanos italianos. Que luego de la detención de su marido tras el copamiento del Comando de Sanidad del Ejército, mientras lo visitaba en el penal de Río Gallegos, fue también detenida y luego liberada por intercesión del cónsul italiano de Bahía Blanca. Sin embargo en abril de 1975 fue nuevamente privada de su libertad junto a un colega abogado: "quedan claras dos cosas: el peregrinaje en busca de los presos políticos a que son obligados los familiares, para ser luego represaliados inclusive hasta la muerte; la caducidad del principio universalmente reconocido de defensa en juicio a causa de la liquidación de la división de poderes, y privados de defensores no por decreto sino por al violencia irracional descargada sobre ellos". Tras enumerar los casos de defensores de presos represaliados, explicaba que había vuelto a ser detenida en marzo de 1976, trasladada a la ESMA y que su sobrevida en Devoto sólo era atribuible a la presión de la embajada italiana. A principios de 1977 reclamaba a través de la CADHU, para que Pax Romana y la Comisión Internacional de Juristas intercedieran por su libertad y la de su esposo y los miles de presos políticos. Recordemos que Eduardo Anguita acreditaba para entonces un largo periplo carcelario que incluía las unidades de Caseros, Resistencia, Río Gallegos, Rawson y la UP 9 de La Plata (CADHU Madrid. Documento, 14/1/1977). Su madre, Matilde Vara de Anguita, participaba activamente de las actividades de solidaridad con los presos políticos al momento de ser secuestrada en julio de 1978. Aún permanece desaparecida.

61 Triunfo, 1/4/1978.

${ }^{62}$ Idem. 
detenciones, prisiones y destierros"63, "respeto a la integridad física" y contra el "sometimiento a tortura, penas y tratos crueles, inhumanos y degradantes" y "violación del derecho de asilo"64. En este mismo contexto debe comprenderse la constante preocupación de la CADHU por la situación de $\operatorname{asilados}^{65}$ y refugiados conosureños ${ }^{66}$, extranjeros residentes en la Argentina (especialmente europeos) ${ }^{67}$ y por los argentinos huidos en tránsito por los países de la región.

Más allá de "las acciones urgentes" por detenidos concretos, de las campañas de información y denuncia en foros nacionales e internacionales ${ }^{68}$, la CADHU trabajó intensamente por sistematizar la información provista por compañeros liberados que ayudaban a explicar la cotidianeidad del tratamiento carcelario en diferentes unidades, en particular Devoto, Coronda ${ }^{69}$, Sierra Chica, Rawson y UP 9 de La Plata ${ }^{70}$. Como explicaba Rodolfo Matarrollo en su carta de renuncia al Comité Exterior (París, 7/7/1979), ese trabajo "condujo a la confección de una lista y varios informes que trata[ron] de analizar los métodos que la dictadura v[enía] aplicando en las prisiones con finalidades de aniquilamiento físico y moral". Por último señalar, que la CADHU también movilizó junto a la COSOFAM, la Comisión Argentina de Solidaridad (CAS), el COSPA, los Trabajadores y Sindicalistas Argentinos en el Exilio (TYSAE) y otras agrupaciones del exilio mexicano, la publicación en 1981 de un pequeño libro de poemas, relatos y dibujos titulado Desde la cárcel. El libro fue presentado en la "Semana del preso político argentino" celebrada en México DF, evento que contó con la presencia del escritor Humberto Constantini, también integrante de la CADHU. ${ }^{71}$

\footnotetext{
${ }^{63}$ Para analizar su posición respecto a los detenidos PEN y sobre la aplicación arbitraria del derecho de “opción”, véase CADHU París. Bulletin, noviembre-diciembre 1977, nº 1 .

${ }^{64}$ CADHU Madrid Mensaje a la comunidad internacional, agosto 1980.

${ }^{65}$ También denunció la situación de los argentinos alojados en la embajada mexicana con especial atención a la del ex presidente Cámpora, solicitando el otorgamiento del salvoconducto que le permitiera salir del país (CADHU París. Bulletin, noviembre-diciembre 1977, $\mathrm{n}^{\circ} 1$ ).

${ }^{66}$ Resulta interesante consignar que la CADHU insistía, por un lado, en la continuidad entre el gobierno constitucional y militar en cuanto a la política restrictiva y punitiva sobre los extranjeros residentes en el país; $y$, por el otro, en que las operaciones de coordinación represiva y persecución extraterritorial de sus exiliados fue una práctica ya instalada durante el gobierno de Isabel Perón. Asimismo la CADHU denunciaba actos de intimidación sobre diferentes agencias de ayuda a los refugiados que actuaban en el país (ACNUR, Comisión Católica de Inmigración) y alertaba sobre las sistemáticas "protestas de inocencia", negaciones abiertas sobre detenciones o desapariciones de refugiados e invenciones de "conspiraciones exteriores", utilizadas por la Junta para frenar el reclamo internacional (CADHU, Argentina. Proceso..., op. cit., 90-104).

${ }^{67}$ En mayo de 1978, en una audiencia pública sobre Argentina organizada por el Grupo Socialista del Parlamento Europeo, Rodolfo Mattarollo expuso sobre las detenciones de miles de personas en los últimos dos años, las detenciones sin causa ni proceso, la tortura, la recepción de prisioneros por diversos países y la desaparición y detención de más de 100 ciudadanos de países miembros de la comunidad europea" (CADHU París. Boletín, $n^{o}$ 4. Junio-julio 1978).

${ }^{68}$ Resulta interesante observar que la CADHU difundió tempranamente "testimonios de presos políticos" del mismo modo que luego lo hizo con los de los "sobrevivientes" de los campos (el caso más sonado el de las ex detenidas desaparecidas liberadas de la ESMA, Ana M Martí, Alicia Miliá de Pirles y Sara Solarz de Osatinky, octubre de 1979) y de algunos represores (Inspector de la Policía Federal Rodolfo Peregrino Fernández, ex ayudante del General. Albano Harguindeguy entre 1976 y 1981 (difundido por COSOFAM Barcelona, 1983).

${ }^{69}$ CADHU Madrid. Boletín $n^{\circ} 13,7 / 3 / 1978$.

${ }^{70}$ CADHU. Madrid Boletín n ${ }^{\circ}$ 9, 3171/1977.

${ }^{71}$ Yankelevich, Ráfagas de un exilio..., op.cit., 230.
} 


\section{Walter Calamita ${ }^{72}$, de la UP 4 a la "opción" italiana. Aproximación a las articulaciones entre cárcel y exilio desde la documentación de la burocracia penitenciaria}

La historia de Walter Calamita se encuentra inscripta dentro de los múltiples cruces que dan forma al entramado prisión política/exilio. En su historia no sólo se hacen borrosos los límites entre un "adentro" y un "afuera" (de la cárcel, del país, del propio sujeto), sino que también se entrelazan y, en algún punto se confunden, lo íntimo con lo público, lo colectivo con lo individual, lo personal y lo familiar.

El punto inicial de esa trayectoria puede rastrearse en un pasado familiar ligado al Partido Comunista Italiano. Antes de migrar, el padre de Walter se había desempeñado como Secretario de la Federación Juvenil Comunista en Masa Fermata, un pequeño pueblo de la región de Le Marche ${ }^{73}$. Una vez en Argentina, Primo Calamita se casó y constituyó una familia en la que la discusión política permeó la vida cotidiana de todos sus miembros. ${ }^{74}$ Al llegar a la juventud, sus dos hijos comenzaron a militar en Bahía Blanca: Higinio (el mayor) ingresó a la Universidad Nacional del Sur y se involucró en la estructura del Partido Revolucionario de los Trabajadores, al tiempo que Walter tuvo un activismo estudiantil en el Colegio Nacional de Bahía Blanca. ${ }^{75}$

En la madrugada del 8 de noviembre de 1974, ambos fueron detenidos en un operativo llevado adelante por grupos parapoliciales y miembros de las Fuerzas Armadas y

\footnotetext{
${ }^{72}$ La elección de la trayectoria vital de Walter Calamita guarda relación con varias cuestiones. Por un lado, su compromiso testimonial a lo largo del tiempo. En tal sentido la posibilidad de poner en diálogo su testimonio durante la dictadura y en el exilio italiano publicado en el libro Quebrantos, con la construcción del testimonio realizada por las autoras en 2014, resultaba en sí misma una buena razón. La segunda que su biografía - enlazada a la de su hermano y la de sus padres - permiten ver las alternativas de la secuencia represiva cárcel-exilio y de la secuencia militante interior-exterior del país. La tercera que se trata de un preso bahiense, que pasó por la UP4 antes de ser trasladado a La Plata y más tarde salir del país, y en tal sentido, la investigación contribuía a la reconstrucción de lógicas situadas en nuestra ciudad de residencia.

${ }^{73}$ Relato de Walter Calamita, Italia, 1978/1979, en: Fanego op.cit.,186

${ }^{74}$ Walter Calamita explicaba la incidencia de ese clima familiar en su formación política: “...En mi casa, Marx, Lenin, y Engels eran como de la familia, se hablaba de ellos continuamente. Recuerdo que cuando tenía 7 años yo sabía perfectamente quién era Lenin, y en la escuela primaria yo decía casi con orgullo que era izquierdista, comunista. Todo esto lo escuchaba y asimilaba en mi casa, como otros niños aceptan la religión (Relato de Walter Calamita, Italia, 1978/1979 en: Fanego, op.cit, 186) “...Yo me acuerdo cuando llegaban los discos del Pocho, de Perón en el exilio, mi viejo era uno de los pocos que tenía combinado, mi viejo era comunista, los comunistas nunca fueron peronistas, pero se reunían clandestinamente. Me acuerdo que mi vieja decía: ¡Ustedes vayan y no cuenten! Me acuerdo que venía la gente, los hombres a mi casa a reunirse para escuchar en el combinado en un volumen muy bajo, para que no escuchara el vecino que podía ser, digamos, contrario. El de la esquina era antiperonista o sea que no tenía que escuchar, el otro era gallego y también no sabías cómo la pensaba. O sea que eso, que en mi casa se reunían clandestinamente, la historia de mi viejo (...) Entonces todo eso hace que vos te vayas formando y que mi viejo leyera el Almanaque Internacional donde conocí a Patrice Lumumba, (...) que conociera las injusticias del mundo, la guerra del ‘48 de Israel, Yasser Arafat, Nasser, todo eso para mí eran nombres de familia. Claro, entonces vos llegás a una condición de joven apoyado sobre conocimientos que por ahí otros chicos no conocían, entonces vos tenés una formación, ¿no? Tenés un espíritu por lo menos de curiosidad hacía ciertas cosas. Sentís toda la vida hablar de las injusticias..." (Entrevista a Walter Calamita, Bahía Blanca, 11/3/2014).

${ }^{75}$ Entrevista a Walter Calamita, Bahía Blanca, 11/3/2014.
} 
de Seguridad. Se trató de un procedimiento que comenzó en una casa operativa del PRT que había sido alquilada tiempo antes con la garantía de Primo Calamita a pedido de su hijo mayor. La patota que ingresó al lugar secuestró y torturó a Gerardo Saad; luego se dirigió a la casa de la familia Calamita, y en el marco de un operativo que implicó corte de calles e incluyó una cantidad significativa de personas que ingresaron por distintos sectores de la vivienda, fueron detenidos Walter, Higinio y su esposa. La labor del grupo de tareas concluyó en el peladero de pollos Calamita, donde la misma patota detonó bombas que dañaron las instalaciones ${ }^{76}$.

Todos los detenidos fueron llevados a la Comisaría $2^{\circ}$ y allí permanecieron alrededor de una semana hasta que fueron trasladados a la cárcel de Villa Floresta (UP 4). ${ }^{77}$ A partir de ese momento, Higinio y Walter pasaron a formar parte de un universo carcelario que inmediatamente comenzó a recoger/producir información sobre ellos y su círculo de relaciones. En las hojas de sus legajos se acumulan tanto los minuciosos registros que ponen al descubierto ciertos aspectos del día a día intramuros (sanciones disciplinarias, informes médicos, etc.), como las idas y vueltas de expedientes judiciales, las reiteradas solicitudes de salidas del país, los decretos denegatorios o habilitantes del Poder Ejecutivo, las notificaciones a la Dirección de Migraciones, los tráficos de radio, entre otros.

Si los "papeles" de la burocracia carcelaria permiten hacer una aproximación a fragmentos de la experiencia vital de Higinio y Walter en las unidades ${ }^{78}$ del Servicio Penitenciario Bonaerense (SPB), no es menos cierto que esos mismos registros nos dan la posibilidad de seguir sus trayectorias y sus vínculos más allá de las fronteras del penal. Al trascender sus muros, en primer plano aparecen sus padres, que movilizaron los trámites judiciales seguidos por el abogado defensor de los dos jóvenes en el marco de la causa que tramitó primero el juez subrogante Marcelo Aníbal Betnaza, y luego el magistrado bahiense Guillermo Federico Madueño ${ }^{79}$. En el expediente ${ }^{80}$ estaban imputados además la esposa de Higinio, Gerardo Saad y Daniel Abot, por infracción al artículo 189 bis del Código Penal y a la ley 20.840 (art. $2^{\circ}$ incisos a y c y artículo $3^{\circ}$ inciso c). ${ }^{81}$

\footnotetext{
${ }^{76}$ Idem.

77 A excepción de Coralia, la esposa de Higinio. Al ingresar a la comisaría estaba embarazada de siete meses y dio a luz la noche de la detención. El personal policial la llevó al Hospital Municipal y allí nació la hija de la pareja (Entrevista a Walter Calamita, Bahía Blanca, 11/3/2014).

${ }^{78}$ Walter Calamita estuvo encerrado en la UP4 y en la UP2, Higinio también permaneció en estas cárceles y luego fue trasladado a la UP 6 de Rawson y a la UP 9 de La Plata.

${ }^{79}$ Se debe tener en cuenta que el juez Guillermo Federico Madueño formó parte de la trama de complicidades civiles del Terrorismo de Estado en Bahía Blanca. Entre las acusaciones que recayeron en su contra se incluye, entre otras cosas, la falta de investigación en casos de denuncias por torturas, la omisión de ordenar la atención médica de las víctimas, los estrechos vínculos que mantuvo con los principales responsables del plan sistemático represivo en la ciudad. Véase la denuncia presentada por el Centro de Estudios Legales y Sociales (CELS), ante el Presidente del Consejo de la Magistratura (Enrique Santiago Petracchi), Buenos Aires, $11 / 5 / 2005$.

${ }^{80}$ Se trató de la causa No 753 del año 1974, caratulada "Saad, Gerardo Darío; Calamita, Higinio Roberto; Calamita, Walter Oscar; Calamita, Coralia Elizabeth Amin Díaz de; y Abot, Daniel Alberto (prófugo) s/ Inf. art. 189 bis C.P. y ley 20.840, art. $2^{\circ}$ incs. a) y c) y art. $3^{\circ}$ inc. c) B. Blanca” (Legajo Walter Calamita, UP 2 Sierra Chica).

${ }^{81}$ Legajo penitenciario de Walter Calamita, UP 2 de Sierra Chica, 1975/1976.
} 
Cuando los múltiples intentos por obtener la libertad resultaron infructuosos ${ }^{82}$, el único "afuera" de la cárcel era un "afuera" del país y ese fue el destino final de todos los miembros de la familia Calamita detenidos y no detenidos. Pero los viajes se sucedieron en el tiempo y en los legajos penitenciarios puede leerse esta historia familiar de encierros/destierros desacompasados. Las gestiones llevadas adelante por los abogados defensores entre 1974 y 1975 dieron por resultado el sobreseimiento definitivo de Walter y su salida del país mediante el "derecho de opción" que le fuera concedido por Resolución Ministerial $\mathrm{N}^{\circ}$ 2875. El 22 de diciembre de 1975 fue notificado de la inexistencia de impedimentos legales para abandonar Argentina y el 12 de enero del año siguiente fue trasladado a Coordinación Federal por la Policía de Azul, donde permaneció durante 10 días hasta que logró emprender el viaje a Italia $^{83}$. En esa última etapa de encierro en Coordinación Federal, Walter sintió con claridad que no sólo su vida e integridad física estaban en manos de las fuerzas de seguridad, sino que su libertad efectiva no dependía estrictamente de la acción de un juez, del decreto del Poder Ejecutivo o de la intervención del Ministerio del Interior a través de la Dirección General de Migraciones. Los testimonios de Calamita y los registros penitenciarios muestran que aún antes del golpe de Estado, los presos políticos "legales" carecían de cualquier derecho, incluso el de salir de territorio argentino con documentación personal. De hecho, Walter subió al avión esposado y sin ningún papel que acreditara su identidad. Sus documentos le fueron devueltos por el comandante de la aeronave tras sus ruidosas protestas cuando aterrizó en Europa. Esta práctica habitual para los "opcionados" servía a dos propósitos: el primero, reforzar la parálisis por el terror; el segundo, asegurarse que el "deportado" no cambiara su destino, convirtiéndose en una amenaza desde el exterior.

Mientras Walter lograba traspasar los muros del penal atravesando fronteras, Higinio quedaba encerrado en los pliegues de expedientes judiciales, de solicitudes de salida del país denegadas y decretos del Poder Ejecutivo en el mismo sentido. Aunque fue absuelto en la causa seguida por el Juez Madueño en febrero de 1977 y se ordenó su libertad, una vez que el fallo fue confirmado por la Cámara Federal de Apelaciones de Bahía Blanca; sólo pudo salir del penal en régimen de "libertad vigilada" 84 tras un largo periplo por diferentes unidades en julio de 1981. Durante todos esos años, solicitó salir del país en varias oportunidades pero siempre obtuvo una respuesta negativa (18/4/1977, 3/4/1978) o el trámite se dilató sin resolución $(26 / 9 / 1979,23 / 6 / 1980) .{ }^{85}$

\footnotetext{
${ }^{82}$ El juez de la causa dictaminó que Walter Calamita debía quedar en libertad por resolución del 25 de abril de 1975, pero la misma no pudo hacerse efectiva por hallarse a disposición del PEN. Higinio, por su parte, fue sobreseído de forma definitiva el 8/2/1977 pero continuó preso a disposición del PEN hasta el 21/7/1981.

${ }^{83}$ Legajo de Walter Calamita, UP 2.

${ }^{84}$ Higinio Calamita debió cumplir la "libertad vigilada" en la localidad de Bahía Blanca con autorización para desplazarse dentro del ejido urbano y bajo supervisión de la Policía de la Provincia de Buenos Aires (Legajo de Higinio Calamita, UP 9 La Plata, 1981). De acuerdo al artículo 6 de la ley 21.650 las personas que se encontraban en esta situación debían “A) presentarse espontáneamente ante las autoridades militares de Seguridad o Policiales que les hayan sido asignadas, cada tres días los dos primeros meses de estar sometido a esta forma de arresto y cada siete días después de ese período (...), C) abstenerse de realizar cualquier actividad que le sea específicamente prohibida por las autoridades competentes D) abstenerse de participar de reuniones públicas, privadas de cualquier naturaleza, excepto las de mero carácter familiar".

${ }^{85}$ Legajos de Higinio Calamita, UP 2 Sierra Chica, 1975-1979 y UP 9 La Plata 1981.
} 
El exilio de Walter y la cárcel de Higinio están anclados en una materialidad que resiste el paso del tiempo. Pero los "papeles" producidos por el sistema penitenciario no son los únicos que emergen a la superficie. De la mano de los recuerdos de los protagonistas brotan dibujos, objetos construidos durante el encierro, cartas, cuentos ${ }^{86}$; pero también tabiques y distancias. Esto registros dispares nos permiten entender que Walter se sitúa en un territorio de múltiples herencias, el compromiso político de su progenitor, la militancia de su hermano, las angustias de unos padres que tuvieron que edificar, una vez más, sus vidas en su país de nacimiento porque el que habían elegido para "hacerse la América" se convirtió en un sitio hostil e inhabitable ${ }^{87}$.

Con esos legados en su valija, Walter llegó a Italia y comenzó una vida lejos pero nunca tan cerca del encierro. Su exilio europeo y sus complejos recorridos militantes en Italia estuvieron marcados por la prisión de Higinio. Walter siempre tuvo presente que su actuación en el exilio podía incidir (positiva o negativamente) en la suerte de su hermano y por esos sus resoluciones militantes (su participación en el CAFRA, su involucramiento en las escuelas políticas del PRT-ERP88 y hasta abortar el proyecto de sumarse al "retorno organizado" ${ }^{89}$ a la Argentina ${ }^{90}$ ) no pueden comprenderse sino en la articulación entre cárcel y exilio.

\section{A manera de cierre}

Este trabajo se propuso revisar las agendas de dos subcampos de la Historia Reciente de notable crecimiento en los últimos años, invitando a descubrir la potencialidad de un territorio fronterizo entre destierros y encierros dictatoriales, desde la formulación de nuevas preguntas a fuentes "clásicas" de las respectivas historiografías, o desde la exploración sistemática de nuevas huellas que iluminan de manera evidente las articulaciones entre estas dos modalidades represivas y militantes.

$\mathrm{Si}$ bien las historiografías de otros regímenes represivos del siglo XX contemporáneos al "Proceso de Reorganización Nacional" o de la Europa de entreguerras,

\footnotetext{
${ }^{86}$ A modo de ejemplo puede hacerse referencia a un cuento escrito por Higinio durante su permanencia en la cárcel titulado "Boxeo y resistencia en la prisión $\left(\mathrm{n}^{\circ} 60\right)$ " que fue publicado mucho tiempo después en "El Otro País de este mundo" Disponible en: http://www.elotropais.com

${ }^{87}$ El relato de Walter pone en evidencia el compromiso que asumió con sus padres una vez que la familia volvió a reunirse en Italia: “...Los viejos después que les desarmaron el peladero, que le desarmaron la familia, la odisea, yo la llamo la odisea. Entonces ¿qué hacés con esa gente? ¿La dejás tirada?, vos te salvaste, me caso, tengo hijos y me dedico a mi familia definitiva, y los viejos que le hacés? todo el sufrimiento o las aspiraciones que tenían sobre vos, ¿adónde la tiras?, ¿por la borda?, ¿o te pones a trabajar para que ellos tengan una vejez feliz?...” (Entrevista a Walter Calamita, Bahía Blanca, 11/3/2014)

${ }^{88}$ Cacho Narzole, Tributo a Naviante. Escuela de militancia, Buenos Aires, Imago Mundi, 2006.

${ }^{89}$ Sobre los planes de regreso a la Argentina de los militantes del PRT-ERP, véase Vera Carnovale, "El PRTERP en el exilio. Armas, comunismo y derechos humanos", Revista de Historia, nº 15, Neuquén, 2014.

${ }^{90}$ Durante su exilio italiano, Walter tomó la decisión de hacer la escuela de guerra para luego trasladarse a México, desde donde su partido se preparaba para retornar a Argentina. Cuando su padre viajó a Italia para intentar disuadirlo de abandonar ese proyecto, los únicos argumentos posibles fueron los relacionados con el encierro de Higinio: “...le digo: ¡Viejo no me vengas a discutir políticamente porque vengo de la escuela, vengo cargado, vengo con todas las pilas llenas y te voy a matar! Entonces mi viejo se me queda mirando. Si me querés pedir algo decime que mi hermano no sale de la cárcel por culpa mía, por mi militancia acá. Y estaba la respuesta, me la estaba dando solo. Si es por mi hermano, me paro acá..." (Entrevista a Walter Calamita, Bahía Blanca, 11/3/2014).
} 
por caso la España franquista - cuentan con campos de estudio delimitados en el mismo sentido, no es menos cierto que tanto en la identificación de los sujetos de la Historia y en la utilización de conceptos problematizadores, como en las formas de periodización y en las transformaciones de los cuestionarios, la Historia Reciente en la Argentina ha mostrado un notable acompasamiento con los ritmos, énfasis y formas de las luchas sociales por la memoria. En este contexto, consideramos que la escritura del pasado de presos políticos y exiliados ha asumido - no siempre de manera crítica - modos de clasificación propios del trabajo humanitario o de la Justicia Transicional (un universo de las "víctimas" integrado por muertos, "desaparecidos", torturados, presos, exiliados), y ha sido atravesada por formas de nominación/evaluación de trayectorias personales o colectivas propias del campo político.

Constatar con de Certeau ${ }^{91}$ que la Historia en general es una "operación”, esto es que se define en la combinación de prácticas científicas, lugar social y escritura; y asumir con Hartog ${ }^{92}$ que el "régimen de historiografía" del pasado reciente no puede divorciarse del régimen de historicidad de la sociedad "presentista", no impide a los investigadores interrogarnos sobre las potencialidades y límites de nuestros cuestionarios; o sobre si nuestras herramientas conceptuales operan verdaderamente como instrumentos analíticos o duplican miradas nativas no dejando reponer los contextos múltiples de sentido que explican procesos y acontecimientos, impidiendo descubrir otros objetos u obturando una lectura auténticamente histórica, contingente y situada.

Creemos que estamos en un momento óptimo de acumulación como para ensayar desde la reconstrucción sistemática de las articulaciones entre cárcel y exilio durante la vigencia del Estado de excepción, otros caminos para pensar la historia de la represión, sus dispositivos, su temporalidad, sus marcas locales; y también para revisar la historia de la militancia, en sus estrategias, continuidades, rupturas y resignificaciones pre y post golpe, sin jerarquías (víctimas mayores y menores, muertos-desaparecidos y sobrevivientes), sin miradas normativas (un "adentro" y un "afuera") y en un diálogo de escalas (nacional, internacional, regional, local).

Recibido: 27 julio 2015

Aceptado: 4 octubre 2015

\section{Referencias bibliográficas}

Águila, Gabriela, "La represión en la historia reciente argentina: fases, dispositivos y dinámicas regionales”, Gabriela Águila y Luciano Alonso (coords.), Procesos represivos y

\footnotetext{
${ }^{91}$ Michel de Certeau, La escritura de la Historia, México, Universidad Iberoamericana, 1993, 68.

92 François Hartog, "Sobre la noción de régimen de historicidad. Entrevista con...", Christian Delacroix, François Dosse y Patrick García, Historicidades, Buenos Aires, Waldhuter Editores, 2010,154.
} 
actitudes sociales. Entre la España franquista y las dictaduras del Cono Sur, Buenos Aires, Prometeo, 2013.

Alonso, Luciano, Defensa de los Derechos Humanos y cultura política entre Argentina y Madrid, 1975-2005, Tesis de Maestría, Universidad Nacional de Andalucía, 2010.

Azconegui, Cecilia, "Chilenos en Argentina, entre la protección del Alto Comisionado de las Naciones Unidas para los Refugiados (ACNUR) y la política de expulsión de la dictadura militar", Silvina Jensen y Soledad Lastra (eds.), Exilios: militancia y represión Nuevas fuentes y nuevos abordajes de los destierros de la Argentina de los años setenta, La Plata, EDULP, 2014.

Bernardotti, Adriana y Bárbara Bongiovanni, "Aproximación al estudio del exilio argentino en Italia", Pablo Yankelevich (comp.), Represión y destierro. Itinerarios del exilio argentino, La Plata, Al Margen, 2004.

Brocato, Carlos, El exilio es nuestro, Buenos Aires, Sudamericana-Planeta, 1986.

CADHU, Argentina. Proceso al genocidio, Madrid, Elías Querejeta, 1977.

Calveiro, Pilar, "Introducción”, Santiago Garaño, y Werner Pertot, Detenidos-Aparecidos. Presas y presos políticos desde Trelew a la dictadura, Buenos Aires, Biblos, 2007.

Carnovale, Vera, "El PRT-ERP en el exilio. Armas, comunismo y derechos humanos", Revista de Historia, n $^{\circ}$ 15, Neuquén, 2014.

Casola, Natalia, "El Partido Comunista de Argentina y el exilio en Europa durante la última dictadura militar. Caracterizaciones políticas, alianzas y disputas", Actas de las Jornadas de trabajo: exilios políticos del cono sur en el siglo XX, La Plata, UNLP, 2012. Disponible en: http: //jornadasexilios.fahce.unlp.edu.ar/ponencias, consulta 1/3/2014.

Chama, Mauricio, "Movilización y politización: abogados de Buenos Aires entre 1968 y 1973”, Anne Perotin-Dumon, (dir), Historizar el pasado vivo en América Latina, 2007. Disponible en: http://etica.uahurtado.cl/historizarel pasadovivo7es_contenido.php, consulta 20/4/2014.

D'Antonio, Débora, "Represión y resistencia en las cárceles de la última dictadura militar argentina", La revista del CCC [en línea], ${ }^{\circ}$ 2, enero-abril de 2008. Disponible en: http: //www.centrocultural.coop/revista/articulo/29/, consulta 22/4/2014.

D'Antonio, Débora, "Políticas de desarticulación de la subjetividad sexual y de género practicadas en la cárcel de Villa Devoto durante la última dictadura militar argentina (19761983)", Estudios, nº 25, Córdoba, enero-junio 2011. 
De Certeau, Michel, La escritura de la Historia, México, Universidad Iberoamericana, 1993.

Fanego, Delia Ana (comp.), Quebrantos. Historias del exilio Argentino en Italia, Buenos Aires, Ediciones Fabro, 2010.

Filc, Judith, Entre el parentesco y la politica. Familia y dictadura, 1976-1983, Buenos Aires, Biblos, 1997.

Filc, Judith, "La cárcel de la dictadura: el poder reparador de la memoria compartida", Marcela Nari y Andrea Fabre (comps.), Voces de mujeres encarceladas, Buenos Aires, Catálogos, 2000.

Franco, Marina, El exilio. Argentinos en Francia durante la dictadura, Buenos Aires, Siglo XXI Editores Argentina, 2008.

Franco, Marina y Florencia Levín, "El pasado cercano en clave historiográfica", Historia Reciente. Perspectivas y desafíos de un campo en construcción, Buenos Aires, Paidós, 2007.

Franco, Marina y Pilar García Bernaldo, "Cuando el sujeto deviene objeto: la construcción del exilio argentino en Francia", Pablo Yankelevich (comp.), Represión y destierro. Itinerarios del exilio argentino, La Plata, Al Margen, 2004.

Garaño, Santiago y Werner Pertot, Detenidos-aparecidos. Presas y presos políticos desde Trelew a la dictadura, Buenos Airess, Biblos/Latitud Sur, 2007.

Garaño, Santiago, Entre resistentes e “irrecuperables": Memorias de ex presas y presos políticos (1974-1983), Tesis de licenciatura, FFyL, UBA, 2008 [mimeo].

Garaño, Santiago, "Los pabellones de la muerte de la Unidad 9 de La Plata. Los límites difusos entre la represión legal y la clandestina", Entrepasados, n 34, Buenos Aires, 2008.

Guglielmucci, Ana, Memorias desveladas: Una aproximación a la militancia revolucionaria a través de los recuerdos de un grupo de militantes y ex prisioneras políticas durante la década del setenta en Argentina, FFyL, UBA, 2003 [mimeo].

Guglielmucci, Ana, "Entrelazando memorias: Cuándo, cómo, y qué recuerdan un grupo de ex prisioneras políticas de la "cárcel de Villa Devoto", Avá Revista de Antropología, no 7 , Posadas, junio 2005.

Hartog, François "Sobre la noción de régimen de historicidad. Entrevista con...", Christian Delacroix, François Dosse y Patrick García, Historicidades, Buenos Aires, Waldhuter Editores, 2010. 
Jensen, Silvina, "La historiografía del último exilio argentino: un territorio en construcción", X Jornadas Interescuelas/Departamentos de Historia, UNR y UNL, Rosario, 20-23 de setiembre, 2005, Cd- Rom.

Jensen, Silvina, "Exilio e Historia Reciente. Avances y perspectivas de un campo en construcción", Aletheia, revista de la Maestría en Historia y Memoria de la FAHCE, UNLP, $\mathrm{n}^{\circ}$ 2, vol. 1, mayo 2011. Disponible en: http://www.aletheia.fahce.unlp.edu.ar, consulta 31/3/2014.

Jensen, Silvina "Huidos, opcionados, liberados. Los exilios argentinos de la década de 1970", Beatriz Figallo y María Rosa Cozzani (eds.), Los de adentro y los de afuera. Exclusiones e integraciones de proyectos de nación en la Argentina y Latinoamérica, Buenos Aires, IDEHESI/ Unidad Ejecutora en Red del CONICET, 2013.

Merenson, Silvina, Y hasta el silencio en tus labios..." Memorias de las ex presas politicas del Penal de Villa Devoto en el transcurso de la última dictadura militar en la Argentina, Tesis de Maestría, IDES/IDAES/UNSAM, Buenos Aires, 2004 [mimeo].

Mira Delli-Zotti, Guillermo, "La singularidad del exilio argentino en Madrid: entre las respuestas a la represión de los '70 s y la interpelación a la Argentina posdictatorial", Pablo Yankelevich (comp.), Represión y destierro. Itinerarios del exilio argentino, La Plata, Al Margen, 2004.

Movimiento Peronista Montonero (MPM), Informe sobre la represión en Argentina, 1978, s.p.i.

Narzole, Cacho, Tributo a Naviante. Escuela de militancia, Buenos Aires, Imago Mundi, 2006.

Osuna, Florencia, "El exilio del Partido Socialista de los Trabajadores en Bogotá (19761982) entre los discursos militantes y las miradas policiales", Silvina Jensen y Soledad Lastra (eds.), Exilios: militancia y represión Nuevas fuentes y nuevos abordajes de los destierros de la Argentina de los años setenta, La Plata, EDULP, 2014.

Parcero, Daniel et. al., La Argentina Exiliada, Buenos Aires, CEAL, 1985.

Pisarello, Virginia, "De presos a exiliados: los "opcionados" de la última dictadura militar", XIII Jornadas Interescuelas/Departamentos de Historia, Universidad Nacional de Catamarca, 10-13 de agosto de 2011. Publicado en CD Rom, Catamarca, Editorial Científica Universitaria, Secretaría de Ciencia y Tecnología, Universidad Nacional de Catamarca, 2013.

Quiroga, Hugo y César Tcach (comps.), Argentina, 1976-2006. Entre la sombra de la dictadura y el futuro de la democracia, Rosario, Homo Sapiens, 2006. 
Serra Padrós, Enrique y Melisa Slatman, "Brasil y Argentina: modelos represivos y redes de coordinación durante el último ciclo de dictaduras del Cono Sur. Estudio en clave comparativa y transnacional", Silvina Jensen y Soledad Lastra (eds.), Exilios: militancia y represión Nuevas fuentes y nuevos abordajes de los destierros de la Argentina de los años setenta, La Plata, EDULP, 2014.

Slatman, Melisa, "Terrorismo de Estado y exilio: hipótesis exploratorias para una comparación entre los casos chileno y argentino", I Jornadas de Trabajo sobre Exilios Políticos del Cono Sur en el siglo XX. Agendas, problemas y perspectivas conceptuales, Facultad de Humanidades y Ciencias de la Educación y la Maestría en Historia y Memoria de la UNLP, 26-28 de septiembre de 2012.

Yankelevich, Pablo y Silvina Jensen, "La actualidad del exilio", Pablo Yankelevich y Silvina Jensen (comps.), Exilios. Destinos y experiencias bajo la dictadura militar, Buenos Aires, Libros del Zorzal, 2007.

Yankelevich, Pablo, Ráfagas de un exilio. Argentinos en México, 1974-1983, México, FCE, 2010. 